\title{
Water funds and payments for ecosystem services: practice learns from theory and theory can learn from practice
}

\author{
Rebecca L. Goldman-Benner, Silvia Benitez, Timothy Boucher, \\ Alejandro Calvache, Gretchen Daily, Peter Kareiva, Timm Kroeger and \\ A URELIO RAMOS
}

\begin{abstract}
Payments for ecosystem services (PES) are emerging worldwide as important mechanisms to align investments in human and natural well-being. PES projects are often defined as voluntary transactions where well-defined environmental/ecosystem services (or land uses likely to secure those services) are bought by a minimum of one service buyer, from a minimum of one service provider, if and only if the service provider continuously secures service provision (conditionality). Further criteria of PES include limiting additional objectives and ensuring that payments reward behaviour that would otherwise not occur (additionality). Together these best practices for PES are increasingly accepted as the most efficient means to achieve desired outcomes and are guiding funding for PES projects. We used a series of water funds (watershed-oriented PES projects based on a trust fund model) to examine how theoretical best practices could inform and improve practice and also how theory could learn from practical efforts. We conclude that thoughtful consideration is required when evaluating the promise of a PES approach against a theoretical ideal. We found that requiring conditionality may limit the use of creative finance mechanisms such as trust funds that can provide long-term benefits for conservation and human well-being, and that requiring additionality can exclude benefits from social diffusion and result in the inefficient targeting of PES funds. Finally, public-private partnerships in water funds lead to multiple
\end{abstract}

Rebecca L. Goldman-BenneR* (Corresponding author), Timothy Boucher and Timm Kroeger The Nature Conservancy-Conservation Science, 4245 North Fairfax Drive, Suite 100. Arlington, Virginia 22203-1637, USA. E-mail rebeccagoldman@stanfordalumni.org

Silvia BeniteZ and Alejandro Calvache The Nature Conservancy-Northern Andes Conservation Program, Quito, Ecuador

GRETCHEN DAILY Biological Sciences, Stanford University, Stanford, California, USA

Peter Kareiva The Nature Conservancy-Conservation Science, Seattle, Washington, USA

Aurelio Ramos The Nature Conservancy-Latin America Conservation Program, Cartagena, Colombia

${ }^{\star}$ Current address: Inter-American Development Bank, 1300 New York Avenue NW, Washington, DC 20577, USA

Received 19 February 2011. Revision requested 13 April 2011.

Accepted 27 May 2011. additional/side objectives but partnerships are likely to lower transaction costs and provide transparent, long-term landscape-scale watershed management.

Keywords Additionality, conditionality, payment for ecosystem services, PES, South America, trust fund, water fund

\section{Introduction}

With a growing number of conservation projects aiming to benefit human well-being by providing ecosystem services (the goods and services such as water purification and carbon sequestration that nature provides; Daily, 1997) there is a need for metrics to evaluate the effectiveness of current projects and to determine best designs and enabling conditions for new ones. Many projects that aim to conserve or enhance the provision of ecosystem services, among other conservation benefits, employ what is generally referred to as payments for ecosystem services (PES; Landell-Mills \& Porras, 2002; Porras et al., 2008). A definition of PES and associated best practices has been emerging (Wunder, 2005, 2006, 2007) that is heavily based on economic theory (specifically, efficiency considerations) and is becoming broadly accepted in the academic literature (e.g. Sommerville et al., 2009) and among practitioners (e.g. CIFOR, 2006; Forest Trends et al., 2008). Recently, funding criteria have been guided by these best practices (e.g. Global Environment Facility STAP guidelines; Wunder et al., 2010). Although this provides a rubric for evaluating PES projects, we argue here that some of the criteria would best be expanded or relaxed while recognizing the potential benefits of achieving theoretical ideals. Here we use a series of practical projects to highlight where and how practice can learn from theory and theory from practice.

PES projects aim to provide financial incentives to land owners or managers for implementing conservation actions that benefit others but that they would not have adopted without those incentives (Sommerville et al., 2009). Research indicates that integrating ecosystem services into conservation approaches can diversify the types of stakeholders who provide funding for conservation (Goldman et al., 2008). The use of ecosystem services in projects is 
diverse and widespread (Tallis et al., 2009) but which of these schemes performs best? Given limited funding, which strategies should take priority?

According to the emerging dominant definition, PES projects are those that include voluntary transactions where well-defined environmental (or ecosystem) services (or land uses likely to secure those services) are bought by a minimum of one service buyer, from a minimum of one service provider, if and only if the service provider continuously secures service provision (conditionality; Wunder, 2005, 2007; Dillaha et al., 2007; Southgate \& Wunder, 2007; Engel et al., 2008). Further research on PES best practices has expanded these conditions to include differentiated payments (payments are scaled/proportionate to services returned or actions taken), spatial targeting (e.g. prioritization of landowners based on benefits, risk of loss and opportunity cost), limiting side objectives (few or no additional or supplemental objectives) and additionality (only pay for actions that would otherwise not occur; Engel et al., 2008; Wunder et al., 2010).

PES schemes have received considerable attention (Landell-Mills \& Porras, 2002; Pagiola et al., 2002, 2007; Jack et al., 2008; Sommerville et al., 2009; Farley \& Costanza, 2010) analysing both their theory and practice and the appeal and drawbacks of market creation (Goldman \& Tallis, 2009; Daniels et al., 2010; Koellner et al., 2010; Reynolds et al., 2010). Debate continues about the effectiveness of these financial incentive systems in attracting landowners, their benefit to the poor and the scale of biodiversity benefits they yield (Engel et al., 2008; Porras et al., 2008). Nevertheless, these schemes are no longer rare (Asquith \& Wunder, 2008; Porras et al., 2008).

For economic efficiency and for establishing metrics to determine optimal investments over time, the PES definition may be theoretically ideal but in practice few if any PES projects meet all the criteria (Wunder, 2005). Does this mean such projects are presently not successful or that they will fail in the future? Are donations and conservation investments being spent inappropriately, or is the definition simply too rigid to account for the variable social/ institutional conditions and ubiquitous information constraints in conservation?

Here we compare a set of practical, sustainably financed watershed PES projects, called water funds, with the PES definition advocated by Wunder (2005) and others. Firstly, we introduce the projects and how they function. Secondly, we use three best-practice criteria (conditionality, additionality and limiting side objectives) to answer two key questions: how have and how can water funds learn from proposed PES best practices and modify their approaches to achieve greater efficiency, and how can lessons learned from ongoing PES projects such as water funds demonstrate the required definitional modifications? Thirdly, we discuss a final concern about enforcement mechanisms for PES projects using in-kind or indirect payments and emphasize the need for creative solutions.

We seek to answer these questions for several purposes. Firstly, we hope that in this early stage of experimentation and evolution of PES approaches, funding opportunities will not be restricted to projects that fit the strict PES bestpractice definition. In other words, we argue that the currently prevailing best-practice definition should not be what determines the constitution of a PES project. Water funds are PES, as are many other successful payment approaches that do not meet the ideal advocated. Secondly, we have observed that water funds are replicable in particular areas precisely because they violate some of the best-practice criteria. Thirdly, we want to emphasize the importance of encouraging creativity in PES design whilst using best practices to guide actions to achieve greater economic efficiency wherever possible.

There are numerous PES approaches that do not meet all of the proposed best practices (Engel et al., 2008). We use water funds because the deviations are consistent within these PES projects and help to illuminate further good practices that would help to expand the definition of PES meaningfully. Water funds are more than a financial model: they are an institutional, financial and biophysical mechanism that link water services users to providers through payments. Specifically, we define a water fund as a PES approach that for financial management uses a trust fund managed by an external entity. In addition, water funds share the following criteria: (1) multiple water service users or user groups, (2) payments that support implementation of watershed best-management practices and conservation, and (3) a board of directors with stakeholder representation that decides how to spend the revenue.

\section{What is a water fund?}

With 113 active/operational payment for watershed service (PWS) projects (a type of PES focusing on water-related services; Stanton et al., 2010), water funds are only one of many PES schemes actively focusing on delivery of hydrological services. Each PWS scheme has its own unique characteristics: finance schemes, payment forms, stakeholders involved, activities implemented and institutional arrangements. We focus on how the unique qualities of water funds can benefit from PES ideals and how good practice can help inform PES best practices.

Water funds are increasingly being used in Ecuador and Colombia but are also found in Bolivia and Peru. The central defining characteristic of a water fund is a trust fund financial model that is independently governed for longterm benefits (some for up to 80 years). Other very similar PES projects, such as the case of Pimampiro in Ecuador, also use a sustainable finance source (a savings account) but lack 
the independence, political security and long-term horizon of a trust fund (Wunder \& Alban, 2008). In addition, water funds have an institutional framework composed of key stakeholders who prioritize the use of payments that, at least in part, go towards conservation management of the watershed and biodiversity protection.

There are currently seven operational water funds, with at least four more projected to become operational by 2012 . A wide variety of stakeholders has been involved in the creation of each of these funds. The oldest water fund is Fondo de Protección del Agua (FONAG) in Quito, Ecuador, which was launched in 2000 through the efforts of The Nature Conservancy (TNC) and Fundación Antisana along with key partners such as the mayor of Quito and the Quito water utility. Since its launch, TNC has worked with numerous partners throughout Ecuador and Colombia to operationalize four more water funds: two more in Ecuador and two in Colombia. Beyond these TNC-affiliated and/or supported initiatives, two regional water funds exist in this same general region. One is Fondo Regional del Agua (FORAGUA) launched in 2009 by the municipal governments of the southern region of Ecuador in partnership with Nature and Culture International, an NGO that mainly works in Ecuador and Peru. Another key partner is Corporación para el desarrollo de los Recursos Naturales, an Ecuadorian NGO. This fund includes three provinces. The other water fund is FONACRUZ, initiated by Fundación Natura Bolivia working with the departmental and municipal government in Santa Cruz, Bolivia. All of these water funds aim to provide clean, regular water flows through watershed conservation.

Water funds allow downstream water users (service buyers) to finance upstream provision of a clean, regular supply of water. In all these cases the services originate within natural ecosystems (e.g. public protected areas) but it is the land management and land use by the human communities living on private, public and communal lands in the watershed that determine service delivery; these communities are the key service providers. Water users (e.g. utilities, municipalities and industries) contribute to the fund. In TNC-related funds the contribution is voluntary (although in Quito the municipality has now passed an ordinance requiring that at least $2 \%$ of the fees the water utility collects goes to the water fund but the fee for the individual user has not increased) and with FONACRUZ and FORAGUA some of the financing comes from increased water fees paid by water users (FORAGUA actually used FONAG as a model and has similar municipal ordinances). Each water fund has its own locationdependent objectives and goals but in general they invest in conserving watersheds to improve or maintain water quality for downstream users, maintain regular flows of water throughout the year and maintain or enhance natural ecosystems.
Water funds are governed by a multi-institutional body, i.e. a public-private partnership that includes service buyers, and in some cases sellers, which makes decisions about how to spend water-fund revenue. This partnership accesses opportunities for cost savings by investing in nature for water purification and for regularity of flows (thereby avoiding costs of finding water further from the out-take point; Goldman et al., 2010).

The trust fund of a water fund acts as both a means to finance conservation projects and, in some cases, a reserve fund. The trust is a long-term, sustainable investment. Interest from the trust, additional investments from water users or from other external donors, and a portion of the trust itself may be used to pay for conservation projects, although this varies by water fund. In some cases, such as water funds in Colombia, a portion of the trust's principal creates a reserve fund. This reserve is used to cover some operational costs, to pay for some transaction costs associated with conservation agreements with watershed communities when other payments are not available, and to manage risk but mostly it is used to guarantee long-term, sustainable funding for conservation. Through this finance mechanism and their governing boards, the water funds in the Andean region have brought together a wide variety of stakeholders (e.g. local communities, public agencies, private corporations) to cooperatively decide how to ensure the provision of ecosystem services through investments in biodiversity conservation.

The watersheds in this region of the Andes share conditions that facilitate water fund creation. These include upstream natural ecosystems (forests and, in many cases, páramo; i.e. high-altitude valleys and plains with a variety of lakes and wet grasslands intermingled with shrublands and forest patches). These ecosystems are essential for capturing, storing and regulating the release of water. They are also natural water purifiers and erosion control mechanisms. If these natural ecosystems are converted then water quality, flow regularity and biodiversity can be compromised (Buytaert et al., 2005, 2006, 2007). Many of these watersheds are also home to poor, rural ranching and farming communities that surround the native ecosystems and rely on the rich soils and abundant grasses for grazing and crops. In some areas the use of fertilizers and agrochemicals is increasing, further threatening water quality. Ensuring good conservation management and providing incentives sufficient to discourage further encroachment on, and degradation of, these natural ecosystems can provide long-term protection for the watershed.

Finally, many northern Andean watersheds share downstream users who depend on the water and who are often able to pay for service provision. These users include public agencies such as urban water utilities, municipal and departmental governments, hydropower companies, private industries such as beer companies (specifically SABMiller 
Bavaria) and water bottling companies (such as Tesalia), and others such as sugar cane producers in the Cauca Valley of Colombia where the producers associated under Asocaña are the main buyers of water fund services.

Water funds invest in a variety of strategies in the watershed to ensure service delivery; the activities vary by fund. For example, in many TNC-affiliated funds strategies include training and paying for community-based park guards to support the national system. All the water funds aim to protect natural ecosystems and to work with the watershed communities to implement best-management practices, reforestation and restoration activities. Bestmanagement practices can include fencing off headwaters and riparian areas, planting live fences, managing fires and revegetating (Fundación Natura, 2010; Goldman et al., 2010). In FORAGUA revenue also goes towards land purchase.

The water funds work with the watershed communities on these projects, finding ways to secure or improve livelihoods. For example, many funds finance projects that compensate for potentially negative livelihood impacts from conservation actions (e.g. reduced crop acreage because of riparian revegetation) and that improve social conditions. Such projects include diversifying income sources such as introducing guinea pig farms or of alternative food sources (e.g. organic vegetable gardens) and investments in education.

Given the newness of many of these funds, changes in land use and resource management are only just being measured. FONAG, the oldest fund, has data to indicate that it has revegetated and maintained c. 600 ha of land per year over the past 4 years; reforested 2,033 ha of land with $>2,000,000$ trees; involved 30,500 children in environmental education programmes; hired, trained and employed 11 community-based park guards to help conserve protected areas; and engaged $>200$ families in community development projects in rural basins (FONAG staff, pers. comms.).

In an assessment of three FONAG communityconservation project areas (including c. 62,500 ha of páramo) it was found that the ecosystems have been maintained in a pristine state. Compared to similar sites outside the conservation areas, burning has stopped and cattle grazing, which is critical to hydrological service provision, has been greatly reduced (Buytaert et al., 2006; T. Boucher et al., unpubl. data). Altogether, FONAG is working in watersheds around the Quito metropolitan region that span $>500,000$ ha, of which c. 120,000 ha are intact páramo and c. 50,00o ha are natural forest (Boucher, in press).

\section{Conditionality and 'true' financial sustainability in PES: are both possible?}

In a conventional market (e.g. for an apple or a car) sellers receive payment only if they actually provide the contractually agreed goods or services; best-practice proponents argue the same relationship should exist for PES schemes. The more tightly coupled the relationship between money spent and goods or services received, the greater the conditionality of the payment; i.e. providers/ sellers are paid only if they actually provide the goods or services. The merits of conditionality are clear: it ensures service provision or, alternatively, avoids wasting resources by paying 'money for nothing' (Ferraro \& Pattanayak, 2006), and it ensures that the practices paid for generate net benefits for users, as presumably the latter would otherwise not be willing to purchase those services at the given price. Furthermore, conditionality promotes the development of methods for measuring the impact of conservation investments on ecosystem services. Even proponents of this feature of PES schemes recognize that currently what is paid for, almost ubiquitously, are practices that should return desired services but water funds demonstrate how, even with this relaxed definition, necessitating conditionality can inhibit creative, sustainable finance solutions for costeffective conservation.

As previously described, water funds accumulate money in a trust fund, the interest from which finances conservation. Service buyers are downstream users who contribute to the fund although, in practice, the fund itself is the buyer as it is the source of conservation payments. As only the interest and/or a portion of the principal in the fund are used to finance conservation projects, the trust fund creates a sustainable source of financing. This sustainable finance mechanism violates conditionality because buyers are unable to withdraw their contributions if they perceive that services are not being delivered (although because outcome-based measures are now being implemented in various water funds, providers will be able to know if services are not being delivered). Likewise, if a buyer, such as a water utility, finds a better, more cost-effective investment for decreasing sedimentation, the buyer is unable to withdraw its accumulated contribution in the fund. Buyers or users can stop supporting the fund with additional payments but contributions already made are sunk costs and will continue to generate interest.

There are advantages to using the trust fund as a conservation revenue source. The interest-based, noncapital reducing financing is sustainable and thus not completely vulnerable to market fluctuations (e.g. the devaluing of conservation or watershed management). Sunk contributions also provide an incentive for service users to remain on the board of directors for the long term to influence future investments, which leads to improved understanding and knowledge about conservation and 'green' alternatives and creates a 'knowledge community' of major stakeholders that provides a platform for active engagement and learning about conservation opportunities, approaches and benefits. 
Recognizing both the timely need to invest in conservation projects (it takes time to build interest on the fund's principal) and to create a more direct relationship between user and provider, some water funds have adjusted their financial models and now build a trust fund as a reserve fund whereas the majority of the contributions are spent more immediately on conservation activities in the watershed. Compared with the FONAG model, withdrawing user support in this case means there is significantly less money available for action. For example, in Tungurahua, Ecuador, water fund contributions are managed by a trust but only $60 \%$ goes to capitalize the principal and $40 \%$ finances immediate conservation actions. In Bogota, users' contributions are not yet capitalizing the trust; instead, the water fund is financing actions first to demonstrate progress and results to help attract new contributions.

Even using the trust as a reserve violates PES best practices but confers several advantages. It buys time to seek new donations and revenue if the cost of the environmental externality exceeds the available fund resources while beginning to implement corrective actions immediately. The reserve fund helps weather the impact of short-term market fluctuations that could threaten the viability of PES programmes fully funded from ongoing cash flow and it provides reserve funding for unforeseen management and operational costs not captured in cost estimates for direct actions.

Trust funds can operate in a wide variety of financial and institutional settings; these include both public and private bodies. Securing the investments in a trust and thereby protecting them from political instabilities is one of the major reasons FORAGUA chose to establish a trust fund. Trust-based PES schemes are flexible; the most efficient scheme for a particular PES project depends on local context. If market fluctuations or government intervention could imperil conservation actions, a sustainable trust reasonably well insulated from both could be the most efficient and effective way to provide services. At the same time it is important to recognize that a trust may not be institutionally or politically feasible or that government regulations may favour a different finance mechanism. In Brazil, for example, several PWS projects make use of a government regulation to make direct payments to landowners, with no trust or reserve funds as intermediaries.

Trust funds remove the direct connection between service sellers and individual buyers by interjecting a financial intermediary. In other words, financial sustainability leads to a violation of conditionality. Although over time some water funds have adapted their trust funds to increase conditionality by using them only as reserve funds rather than as the sole financing source for conservation actions, even this violates the conditionality requirement for the ideal PES scheme. However, this can yield great benefits. In evaluating PES projects for possible funding it is therefore important to acknowledge this potential and to relax conditionality as an absolute criterion for qualifying as PES, recognizing some of the benefits of financial sustainability. Ideally, both conditionality and financial sustainability are possible for conservation efforts. However, given market volatility and numerous externalities, and given the current level of outcome-based measures, it may, for now, be worth partially sacrificing one to ensure the other. Failure to recognize the benefits of achieving true financial sustainability, in spite of some sacrifices to conditionality, risks sacrificing good practice to theory.

\section{Additionality: where efficiency assessments ignore the benefits of social diffusion}

Additionality is the incremental gain in service delivery that results from implementing PES compared with the counterfactual baseline (the world that would exist without the project; Wunder, 2007). Establishing the correct baseline is therefore crucial for accurately assessing project outputs, cost-effectiveness and efficiency (Wunder, 2005). Advocates of additionality argue that paying for services that would have been provided in absentia of financial incentives is inefficient (Engel et al., 2008). Ideal participants in PES projects are those landowners who pose a credible and significant (current or future) threat to service provision and who will bear opportunity costs for conservation actions but whose land use is only marginally more profitable than alternatives that conserve ecosystem service flows. Under such conditions, a PES subsidy can have maximum impact (Wunder, 2005).

Several concerns have been raised about additionality as a strict means for judging the effectiveness of PES. Firstly, without a comprehensive, in-depth evaluation of current and future threats, it is difficult to assess the security of currently conserved lands. Because of limited information at a fine spatial scale, in most cases it is difficult to assess the likelihood that one landowner will maintain good stewardship and another will not (e.g. Wünscher et al., 2008). Establishing accurate baselines for measuring additionality can thus be expensive (Sommerville et al., 2009). Secondly, Wunder (2005) notes potential inequities that could arise. Good land stewards, or landowners with small holdings, often do not pose a credible threat to achieving conservation goals and are therefore unable to access the financial incentives of a PES project. Nevertheless, additionality is a key consideration for evaluating PES schemes to ensure efficiency and to avoid investments in environmental service projects that do not yield increases in service flows above the baseline (Ferraro \& Pattanyak, 2006; Wunder, 2007; Engel et al., 2008; Sommerville et al., 2009).

Water funds are starting to use tools to prioritize conservation actions to achieve additionality. For example, 
scientific models (specifically integrated valuation of ecosystem services and trade-off models) have been run in the Cauca Valley of Colombia, the site of the Fondo de Agua por la Vida y la Sostenibilidad (FAPVS) water fund (H. Tallis, pers. comm.), to determine priority areas for investment based on greatest threat. However, even with such baselines an analysis of lowest opportunity cost for greatest service provision and conservation benefits is lacking. Nevertheless, we argue that even if high-quality baseline assessments are conducted for potential PES target areas (such as in FAPVS) they may fail to account for additional benefits stemming from the social dynamics of the region.

Without accounting for social spillover effects (the diffusion of action(s) through a population once the action(s) is taken up by at least one person), additionality cannot be measured accurately. As Yates \& Aronson (1983) argued 'To design effective public policy, the social, cognitive, and personal forces that, in addition to the economic realities, define the situation must be understood'. Social diffusion theory posits that changing the behaviour of a small percentage of people (in some cases as little as $15 \%$ of a population) can have transformational impacts on the entire population (AtKisson, 1999). If the $15 \%$ are those who are easy to convince, who do not require large payments to change behaviour, and who are inclined to continue conservation practices once adopted, then it may be more socially and financially efficient to include these individuals in a project. In the context of PES, this means that it is not necessarily inefficient to target landowners whose actions may not yield high additionality. As commonly measured, however, additionality does not account for these diffusion effects.

We thus argue for caution when evaluating additionality in a PES scheme because benefits from social diffusion may be ignored, and excluding them may result in the inefficient targeting of PES funds. In the Bogota water fund, for example, there is qualitative evidence of peer pressure and community encouragement for participation and for strict enforcement of fund practices, benefits that are now being quantitatively measured in FONAG and FAPVS.

\section{Side objectives: friends or foes?}

Although a particular water user may be interested in specific ecosystem services, individual contributions are pooled and invested in projects that deliver a bundle of services. One key advantage of this collective approach is lower transaction costs compared with those for financing various individual PES projects. Joint decision making can lead to conservation projects that yield a range of benefits. Furthermore, by pooling the contributions of several users, water funds can implement ecosystem service projects on a spatial scale beyond the scope of an individual PES project, thus capturing potential scale effects in service production.

The fund board includes water users and sometimes community representatives (often service providers) and makes decisions about how to use funds. Board members are very diverse. In the Fondo del Agua para la conservación de la Cuenca del Río Paute near Cuenca, Ecuador, for example, the board includes two water companies (interested in water quality and flow regularity), two hydropower companies (concerned about sedimentation), Cuenca University, and TNC and Fundación Cordillera Tropical (concerned about biodiversity conservation).

Because of the varied interests of their board members, water funds necessarily have a variety of objectives, or a main objective and various side objectives, thus violating PES best practices because if the objectives do not align perfectly, one or more stakeholders may invest in actions that are not linked to the results they seek or are not the preferred actions to achieve those results. Hydropower companies, for example, may care more about sedimentation whereas water utilities may care more about faecal coliforms. When service providers have a seat on the board (such as in FAPVS), interests become even more diverse. Joint decision making thus may divert service buyers' investments from the services they most care about.

Nevertheless, we argue that these public-private institutional mechanisms, with their multiple objectives, may in some cases be more efficient despite the challenges the structure poses for achieving strong conditionality. Joint decision making leads to large-scale, integrated watershed management. Water funds bring together stakeholders as different as sugar cane producers and local watershed communities (e.g. FAPVS), and such partnerships provide a way to include social criteria as well as biophysical and economic measures in defining optimal investment portfolios.

\section{Enforcement and in-kind payments: how do we make this work?}

Water funds use a variety of payment types, including indirect and in-kind payments such as materials, manpower and/or expertise to reward farmers and ranchers for changing their management practices. Wunder (2005) highlights the relevance and importance of careful consideration of possible enforcement mechanisms when such payments are used in PES design. Large, non-refundable, up-front benefits or payments do not create strong incentives for long-term service provision (Wunder, 2005) as even with a contract there are no credible penalties for violations. For example, as mentioned earlier, water funds may help diversify family incomes or reduce expenditures by providing supplies and training to plant organic 
backyard gardens or to rear guinea pigs. The benefits are multiple: food security is increased, resources formerly spent on obtaining meat and vegetables can be used elsewhere and nutrition can improve. But what options does the water fund have if a family later removes the fundsponsored fence and again allows its cows to enter the river? Ripping up the organic garden or taking back the guinea pigs surely would not be morally defensible sanctions for contract violations.

Payment in the form of educational infrastructure provides another example. No organization is going to tear down a school it helped to finance (Wunder, 2005) or to stop teaching children because one child's family is not in compliance with the PES project. Beyond blacklisting the family or community for future PES programmes, there are no obvious means of promoting compliance with PES contracts. In other words, how do water funds stop paying families when they are not paying them directly in the first place? This problem is faced by any programme that includes up-front payments of any kind, not just water funds. There is no question that enforcement is necessary but, as Wunder (2005) discusses and as practical experience demonstrates, such issues are not easily resolved.

Thus, if up-front or in-kind payments are the only option (if service buyers want to make in-kind payments only, if service sellers prefer alternatives to cash, or if government restrictions do not allow cash payments) ensuring enforcement is a challenge. We see this as a valuable new field of research and inquiry, with the opportunity to learn from projects that have used these forms of payments. One possibility may be to launch all conservation activities communally. In Bogotá, for example, the major water utility (Empresa de Acueducto y Alcantarillado de Bogotá) has been working on community conservation projects for a number of years. As in projects soon to be launched by the Bogotá water fund, families engage in conservation activities such as fencing areas around rivers. To encourage communal enforcement members of participating households erect the fences together on all participants' properties (in this case it is often a group of women). Any family that tries to renege on contract requirements, for example by putting their fence closer to the river than stipulated in the PES contract, faces intense peer pressure that, thus far, has virtually ensured compliance. Mechanisms that enhance the success of community-level enforcement should be studied and better understood because evidence, for now, is largely anecdotal.

\section{Conclusion}

The water fund PES model has been replicated, has catalysed conservation actions and pooled investments to bring them up to scale, and has engaged new stakeholders in financing conservation. Nevertheless, despite the fact that they are PES models, water funds do not exhibit all PES best practices and, therefore, despite certain advantages, they would not even be evaluated for potential funding if that funding were based only on the theoretical PES ideal. Although a trust fund violates conditionality (the direct connection between the ecosystem service user and the service provider) the model offers an important approach for achieving longterm, stable financing for projects that reduce negative environmental externalities in contexts where cash payments are not feasible or institutional complexity or constraints make strict conditionality impractical or too costly. As such, the fund model is an important PES approach that enlarges the set of contexts in which PES solutions can be applied. Likewise, although there is currently not a strong focus on additionality in water funds, attempts to incorporate narrowly defined additionality criteria to improve the economic efficiency of water funds may in fact be counterproductive unless the effects of social diffusion are adequately incorporated into the analysis. Finally, the funds' public-private, multi-stakeholder decision-making mechanism inevitably leads to side objectives but this structure facilitates cross-collaboration, transparent governance, information exchange and learning, and ensures that conservation investments target outputs that are collectively considered desirable.

While the challenge to improve the long-term compliance with contractual agreements for service supply remains, water funds have engaged new stakeholders in conservation efforts, invested in environmental education for both rural and urban children, conserved some of the most diverse ecosystems, and created a model for financially sustainable conservation. In some ways it is the flexibility of the water fund model that allows it to succeed in different institutional contexts. Impact measures to ensure water funds are delivering on their promised objectives are currently being developed and implemented.

\section{Acknowledgements}

We would like to thank all of our partners throughout the Latin American region. Without them there would be no water funds. We also would like to thank Karin Krchnak for helpful comments and revisions and numerous other staff throughout The Nature Conservancy for fruitful discussions and support, helping us to refine our research and our questions, and two anonymous reviewers whose comments greatly strengthened this article.

\section{References}

Asquith, N. \& Wunder, S. (eds) (2008) Payments for Watershed Services: The Bellagio Conversations. Fundación Natura Bolivia, Santa Cruz de la Sierra, Bolivia. 
At Kisson, A. (1999) Believing Cassandra: An Optimist Looks at a Pessimist's World. Chapter 9 - The Innovation Diffusion Game. Chelsea Green Publishing Company, Vermont, USA.

Boucher, T. (in press) A Terrestial Ecological Impact Assessment of the Quito Waterfund. The Nature Conservancy, Arlington, USA.

Buytaert, W., Celleri, R., De Bièvre, B., Cisneros, G.W., Deckers, J. \& Hofstede, R. (2006) Human impact on the hydrology of the Andean páramos. Earth-Science Reviews, 79, $53-72$.

Buytaert, W., Iñguez, V. \& De Bièvre, B. (2007) The effects of afforestation and cultivation on water yield in the Andean páramo. Forest Ecology and Management, 251, 22-30.

Buytaert, W., Wyseure, B., De Bièvre, B. \& Deckers, J. (2005) The effects of land-use changes on the hydrological behaviour of Histic Andosols in south Ecuador. Hydrological Processes, 19, 3985-3997.

Cifor (Center for International Forestry Research) (2006) What are "payments for environmental services"? Http:// www.cifor.org/pes/_ref/about/index.htm [accessed 7 September 2011].

Daily, G. (1997) Nature's Services: Societal Dependence on Natural Ecosystems. Island Press, Washington, DC, USA.

Daniels, A.E., Bagstad, K., Esposito, V., Moulaert, A. \& RodrigueZ, C.M. (2010) Understanding the impacts of Costa Rica's PES: are we asking the right questions? Ecological Economics, 69 , 2116-2126.

Dillaha, T., Ferraro, P., Huang, M., Southgate, D., Upadhyaya, S. \& Wunder, S. (2007) Payments for Watershed Services: Regional Syntheses. USAID PES Brief 7, Washington, DC, USA.

Engel, S., Pagiola, S. \& Wunder, S. (2008) Designing payments for environmental services in theory and practice: an overview of the issues. Ecological Economics, 65, 663-674.

Farley, J. \& Costanza, R. (2010) Payments for ecosystem services: from local to global. Ecological Economics, 69, 2060-2068.

Ferraro, P.J. \& Pattanayak, S. (2006) Money for nothing? A call for empirical evaluation of biodiversity conservation investments. PLoS Biology, 4, e105.

Forest Trends, The Katoomba Group \& UneP (United Nations Environment Programme) (2008) Payments for Ecosystem Services Getting Started: A Primer. Forest Trends and The Katoomba Group. Http://www.katoombagroup.org/documents/ publications/GettingStarted.pdf [accessed 7 September 2011].

Fundación Natura (2010) Fundación Natura Bolivia y Fondo de Agua para Santa Cruz (FONACRUZ), Ganadores del Premio Internacional ReSource 2010 por el manejo sostenible de cuencas hidrograficas del Parque Nacional Amboro. Naturalia, El boletin de Fundacion Natura Bolivia, Santa Cruz, Bolivia.

Goldman, R.L., Benitez, S., Calvache, A. \& Ramos, A. (2010) Water Funds: Protecting Watersheds for Nature and People. The Nature Conservancy, Arlington, USA.

Goldman, R.L. \& Tallis, H. (2009) A critical analysis of ecosystem services as a tool in conservation projects: the possible perils, the promises, and the partnerships. In The Year in Ecology and Conservation Biology (eds R.S. Ostfeld \& W.H. Schlesinger), pp. 63-78. Wiley-Blackwell Publishing, Massachusetts, USA.

Goldman, R.L., Tallis, H., Kareiva, P. \& Daily, G.C. (2008) Field evidence that ecosystem service projects support biodiversity and diversify options. Proceedings of the National Academy of Sciences of the United States of America, 105, 9445-9448.

JACK, B.K., KousKY, C. \& Sims, K.R.E. (2008) Designing payments for ecosystem services: lessons from previous experience with incentive-based mechanisms. Proceedings of the National Academy of Sciences of the United States of America, 105, 9465-9470.
Koellner, T., Sell, J. \& Navarro, G. (2010) Why and how much are firms willing to invest in ecosystem services from tropical forests? A comparison of international and Costa Rican firms. Ecological Economics, 69, 2127-2139.

Landell-Mills, N. \& Porras, I. (2002) Silver Bullet or Fools' Gold? A Global Review of Markets for Forest Environmental Services and their Impact on the Poor. International Institute for Environment and Development, London, UK.

Pagiola, S., Landell-Mills, N. \& Bishop, J. (2002) Making market-based mechanisms work for forests and people. In Selling Forest Environmental Services: Market-based Mechanisms for Conservation (eds S. Pagiola, J. Bishop \& N. Landell-Mills), pp. 261-289. Earthscan, London, UK.

Pagiola, S., Ramirez, E., Gobbi, J., de Haan, C., Ibrahim, M., Murgueitio, E. \& Ruiz, J.P. (2007) Paying for the environmental services of silvopastoral practices in Nicaragua. Ecological Economics, 64, 374-385.

Pagiola, S., Rios, A. \& Arcenas, A. (2008) Can the poor participate in payments for environmental services? Lessons from the silvopastoral project in Nicaragua. Environment and Development Economics, 13, 299-325.

Porras, I., Greig-Gran, M. \& Neves, N. (2008) All that Glitters: A Review of Payments for Watershed Services in Developing Countries. Natural Resource Issues No. 11. International Institute for Environment and Development, London, UK.

Reynolds, T.W., Farley, F. \& Huber, C. (2010) Investing in human and natural capital: An alternative paradigm for sustainable development in Awassa, Ethiopia. Ecological Economics, 69, 2140-2150.

Sommerville, M.M., Jones, J.P.G. \& Milner-Gulland, E.J. (2009) A revised conceptual framework for payments for environmental services. Ecology and Society, 14, 34-47.

Southgate, D. \& Wunder, S. (2007) Paying for Watershed Services in Latin America: A Review of Current Initiatives. Working paper No. 07-07. USAID, Washington, DC, USA.

Stanton, T., Echavarria, M., Hamilton, K. \& Ott, C. (2010) State of Watershed Payments: An Emerging Marketplace. Ecosystem Marketplace. Http://www.foresttrends.org/documents/files/ doc_2438.pdf [accessed 2 September 2011].

Tallis, H., Goldman, R., Uhl, M. \& Brosi, B. (2009) Integrating conservation and development in the field: implementing ecosystem services projects. Frontiers in Ecology and the Environment, 7, 12-20.

W under, S. (2005) Payments for Environmental Services: Some Nuts and Bolts. Occasional paper. CIFOR, Bogor, Indonesia.

Wunder, S. (2006) Are direct payments for environmental services spelling doom for sustainable forest management in the tropics? Ecology and Society, 11, 23-34.

WUNDER, S. (2007) The efficiency of payments for environmental services in tropical conservation. Conservation Biology, 21, 48-58.

Wunder, S. \& Alban, M. (2008) Decentralized payments for environmental services: the cases of Pimampiro and PROFAFOR in Ecuador. Ecological Economics, 65, 685-698.

Wunder, S., Wertz-Kanounnikoff, S. \& Ferraro, P. (2010) Payments for Environmental Services and the Global Environment Facility: A STAP Advisory Document. UNON Publishing Services Section, Nairobi, Kenya. Http://www.unep.org/stap/LinkClick.aspx? fileticket $=\mathrm{N}_{1}-\mathrm{tMo} 87 \mathrm{PkA} \% 3 \mathrm{~d} \&$ tabid $=2912$ \&language $=\mathrm{en}-\mathrm{US}$ [accessed 2 September 2011].

Wúnscher, T., Engel, S. \& Wunder, S. (2008) Spatial targeting of payments for environmental services: a tool for boosting conservation benefits. Ecological Economics, 65, 822-833. 
Yates, S.M. \& Aronson, E. (1983) A social psychological perspective on energy conservation in residential buildings. American Psychologist, 38, 435-444.

\section{Biographical sketches}

Rebecca L. Goldman-Benner researches the links between ecosystem service provision, biodiversity conservation, climate change poverty alleviation and the enhancement of human well-being. S I L I IA BENITEZ works in natural resources management and biodiversity conservation and conservation planning. Tiмотнy Boucher's work applies remote sensing data and spatial analyses to a wide range of conservation issues. AlEJANDRO CALVACHE works on the creation and strengthening of financial mechanisms for the provision of ecosystem services at the watershed scale. Gretchen C. Daily does research that strives to incorporate environmental issues into business practice and public policy. Peter Kareiva studies and tests conservation outcomes to deliver credible tools that allow routine consideration of nature's assets in decision-making. Тімм KROEGER's research focuses on the application of economic valuation, economic analyses of conservation and environmental quality projects, and evaluation of economic incentives for conservation. Aurelio Ramos works on designing innovative, incentivebased conservation financing to improve conservation practice. 